DOI: https://doi.org/10.24127/ajpm.v10i1.3441

\title{
DEFRAGMENTATION THINKING STRUCTURE TO OVERCOME ERRORS IN ADDRESSING MATHEMATICAL PROBLEM
}

\author{
Siti Puri Andriani ${ }^{1 *}$, Triyanto ${ }^{2}$, Farida Nurhasanah $^{3}$ \\ ${ }^{1 *, 2,3}$ Universitas Sebelas Maret, Surakarta, Indonesia \\ *Corresponding author. \\ E-mail: $\quad$ sitipuriandriani17@gmail.com $^{\left.{ }^{*}\right)}$ \\ triyanto@fkip.uns.ac.id ${ }^{2)}$ \\ farida.nurhasanah@fkip.uns.ac.id ${ }^{3)}$
}

Received 30 December 2020; Received in revised form 06 March 2021; Accepted 06 April 2021

\begin{abstract}
This research is intended to describe students' procedural errors in solving problems derivative of algebraic functions and efforts to overcome these errors by using the defragmentation process. Error analysis is carried out based on the procedural error theory based on Elbrink which includes the following aspects of errors: 1) Mis-identification; 2) Mis-generalization; 3) Repair Theory; and 4) Overspecialization. The subjects in this study are students of class XII MIPA Islamic State Senior High School (MAN) 3 Tulungagung taken from snowball random sampling. In taking the subject, the researchers select one of the students who make procedural errors by considering the completeness of the students when solving the given problems based on the problem-solving phase according to Polya. Based on the results of this study, it is found that the procedural errors made by the students are repair theory errors and overspecialization. The defragmenting process to correct these errors is intended to provide dis-equilibration and scaffolding. The results after the defragmenting process are the students can correct their mistakes and the structure of their thinking.
\end{abstract}

Keywords: Defragmenting structure thinking; derivative algebraic functions; problem solving; procedural errors.

\begin{abstract}
Abstrak
Penelitian ini bertujuan untuk menggambarkan kesalahan prosedural siswa dalam menyelesaikan masalah turunan fungsi aljabar dan upaya untuk mengatasi kesalahan tersebut dengan menggunakan proses defragmenting. Analisis kesalahan dilakukan berdasarkan konsep teori kesalahan prosedural menurut Elbrink yang mencakup aspek kesalahan sebagai berikut: Mis-identificstion; 2) Misgeneralization; 3) Repair Theory; dan 4) Overspecialization. Subjek dalam penelitian ini adalah siswa kelas XII MIPA MAN 3 Tulungagung yang diambil secara snowball random sampling. Dalam pengambilan subjek dipilih salah satu siswa yang melakukan kesalahan prosedural dengan mempertimbangkan kelengkapan siswa ketika menyelesaikan masalah yang diberikan berdasarkan tahap pemecahan masalah menurut Polya. Dari hasil penelitian ini ditemukan bahwa kesalahan prosedural yang dilakukan siswa ialah kesalahan repair theory dan overspecialization. Proses defragmenting yang dilakukan untuk memperbaiki kesalahan tersebut ialah dengan memberikan dissequillibrasi dan scaffolding. Hasil yang diperoleh setelah proses defragmenting dilakukan ialah siswa mampu memperbaiki kesalahannya dan struktur berpikirnya.
\end{abstract}

Kata kunci: Defragmenting struktur berpikir, kesalahan prosedural, pemecahan masalah, turunan fungsi aljabar.

This is an open access article under the Creative Commons Attribution 4.0 International License 
DOI: https://doi.org/10.24127/ajpm.v10i1.3441

\section{INTRODUCTION}

Mathematics learning process includes the concrete presentation of mathematical concept. In the Mathematics learning process, the interesting thing is how students construct mathematical concept, and were able to build knowledge by connecting one concept and another (Subanji, 2015). In Mathematics learning process, students experience thinking process. The term thinking is often used to remember something, or in short, thinking process is a complex process happened in someone's mind when he thinks of something (Wibawa, 2016). This is in line with the basic purpose of learning Mathematics in which students are expected to have the ability to solve problems. (National Council of Teachers of Mathematics, 2000). The ability to solve problems is strongly needed by students since it is the basic ability that students should master in solving problems. (Naisunis et al., 2018). Agustina (2014) also stated that thinking process in solving mathematical problems is influenced by several factors, both direct and indirect factors. However, the more influenced factor is the indirect factor such as motivation and self ability. This causes the difference of point of view or opinion in solving problems.

In solving problems, there are some probabilities happens in students' answers. It is possible that students give the correct answer, and are able to give justification toward their answers means that the answers are "certainly correct". In contrast, if students give the correct answers but they are not able to give justification to the answers, the correctness of the answers are "false correctness". Meanwhile, students with wrong answers and fix them after reflection are able to make them correct so it is then correct and called as pseudo-wrong thinking (Wibawa \& Chandra, 2013).The result of students' answers showed that someone can find error in the process of constructing concepts they have previously and connect them into the newest concepts (Efendi \& Pratama, 2020).

Error is a form of deviation towards something that is regarded as correctness or procedure that is fixed before (Rosyidi in Kumalasari, 2016). There are several factors that cause students to experience error in Mathematics learning process. The most often error is when they solve mathematical problems is the miscalculation and procedural error (Elbrink, 2011). The miscalculation happens when students are inaccurate in calculating numbers when they are doing mathematical problems. In the other hand, the procedural error happens because they don't have any right conceptual understanding in Mathematics (Elbrink,2011). In addition, Elbrink explained other errors that mostly happen in solving mathematical problems is: 1) conceptual error; and 2) technical error (Wibawa et al., 2018).

One of Mathematics materials in Senior High School or Islamic High School is Derivative Algebraic Function. It is a compulsory material for students to accomplish especially in Natural Science department or other departments where mathematics is a compulsory subject. In the research conducted by (Apriliyanto, 2019), students were error in the problem understanding stage $7,5 \%$, finishing preparation stage $12,5 \%$, problem solving stage, and verification stage $100 \%$. Based on the type of error, students are error in presenting facts $27,5 \%$, concept $42,5 \%$, principle $37,5 \%$, 
and operation $22,5 \%$. That is in line with Amir (2015) who claimed that derivation is a material learned in Mathematics subject in senior high school or Islamic high school, but still there are so many students who do not accomplish the material well.

Based on the fact, restructuring process is needed since students still have errors in solving Derivative Algebraic Functions problems. The restructuring process is called Defragmenting. It is a process of restructuring students thinking into broader thinking structure so it can reach the deeper understanding and solve problems given (Subanji, 2016). Sakif in (Bahrudin et al., 2019) defined thinking structure defragmenting is a restructuring of students' thinking when having error in solving mathematical problems through the process of disequllibria, conflict cognitive, dan scaffolding so that students can fix their errors. Disequllibria is a condition where someone finds difficulty of confusion that reflects the unbalance between assimilation and accommodation (Subanji, 2015). Conflict cognitive is a condition when students have errors and need a model to shape a conflict so that students will recheck the answer (Subanji, 2015).

There are many researches related to defragmenting students' thinking structure in solving mathematical problems, but there were no researches that focused on defragmenting students' thinking structure as an effort to overcome students' error in solving mathematical problems on Derivative Algebraic Function. In the last ten years, research topics related to defragmenting thinking structure in some countries studied about defragmenting Pseudo thinking process (Efendi \& Pratama, 2020), defragmenting thinking structure (Kumalasari, 2016), and defragmenting Pseudo thinking structure (Wibawa, 2016).

Based on some researches above, it can be concluded that students still have errors in solving Derivative Algebraic Function. This fact shows that students have low problem solving ability. Therefore, defragmenting process is needed to help students restructure their thinking structure. According to (Wibawa et al., 2017, Kumalasari et al., 2016) described generally that defragmenting can fix students' thinking structure to be better in solving mathematical problems. From the problems, it needs deeper analysis related to procedural error done by students in solving problems and how their thinking structure before and after defragmenting process. Therefore, researchers related to defragmenting of students thinking structure as an effort to overcome errors in solving mathematical problems need to be studied. In other words, research is done to describe students' procedural error in solving Derivative Algebraic Function problems and effort to overcome the error using defragmenting process.

\section{METHOD}

The research method is descriptive qualitative. Qualitative descriptive research is used to get a figure of the flow of thinking of the students and the defragmentation process of solving problems given by the students. This research is chosen to conduct an in-depth analysis to get maximum results and appropriate the objectives of the research. At the time of writing this article, the researcher is still in the research process stage.

The subjects in this research are students of class XII MIPA-1 MAN 3 
Tulungagung up to 25 students. In taking the subject, the researchers employ the Snowball Sampling technique or snowball snippet.

The subjects in this research are students who have studied the derivative material of algebraic functions. The criteria for taking the subject are the students who make mistakes by considering the completeness of students when solving problems given based on procedural error indicators according to Elbrink adjusted to Polya's stages in table 1 .

Of the 25 students, several students are taken who are further reduced to being one of the students. Selected students are then interviewed. Interviews are conducted to clarify, explore or clarify the results of the work when solving problems derived from algebraic functions. The research instrument is in the form of test questions and descriptions which validated by expert lecturers (expert judgment). The instrument determines the first derivative of $f(x)=\sqrt{x+2}$. The expert lecturers are Lecturers of Mathematics Education at Sebelas Maret University Surakarta and Lecturers of Mathematics Education at the State Islamic Institute (IAIN) of Tulungagung.

The second instrument is an interview guideline in the form of structured questions about students' thinking processes and the defragmentation activities. During the interview process, research subjects are asked to verbally convey what they think when solving the given problem (think aloud). In this research, the indicators of errors in solving problems can be seen in Table 1 .

Table 1. Indicators of errors in solving problems

\begin{tabular}{|c|c|c|}
\hline $\begin{array}{l}\text { Fault Aspects in } \\
\text { Solving Problems }\end{array}$ & Indicator & Description \\
\hline Misidentification & $\begin{array}{l}\text { Understanding } \\
\text { problem }\end{array}$ & $\begin{array}{l}\text { 1. Students can understand the problems given; } \\
\text { 2.Students can understand concepts related to } \\
\text { the problem given. }\end{array}$ \\
\hline Misgeneralization & $\begin{array}{l}\text { Creating } \\
\text { problem-solving } \\
\text { plan }\end{array}$ & $\begin{array}{l}\text { a 1. Make generalizations about an existing } \\
\text { concept }\end{array}$ \\
\hline Repair Theory & $\begin{array}{l}\text { Carrying out } \\
\text { problem-solving } \\
\text { plan }\end{array}$ & $\begin{array}{l}\text { a 1. Applying an algorithm to a problem; } \\
\text { 2. Determining what steps should be used; } \\
\text { 3. Having a clear direction of work in solving } \\
\text { problems. }\end{array}$ \\
\hline Overspecialization & re-examining & $\begin{array}{l}\text { 1. Providing procedural limitations in solving } \\
\text { problems; } \\
\text { 2. Determining the final result properly and } \\
\text { correctly from the problems given by } \\
\text { checking back the results of the work. }\end{array}$ \\
\hline
\end{tabular}

Based on the test and interview data, the next process is giving the code and making it a basis for describing the structure of students' thinking. After knowing the location of the error, the process that will be carried out is the defragmenting process which aims to re-measure/restructure students' thinking in solving problems of algebraic function derivatives. The flow 
DOI: https://doi.org/10.24127/ajpm.v10i1.3441

of students' thinking or the structure of the problem that is expected to solve the derivative problem of algebraic functions can be explained in Figure 1.
Based on the Figure 1, it can be explained. The explanation of Figure 1 can be seen in Tabel 2.

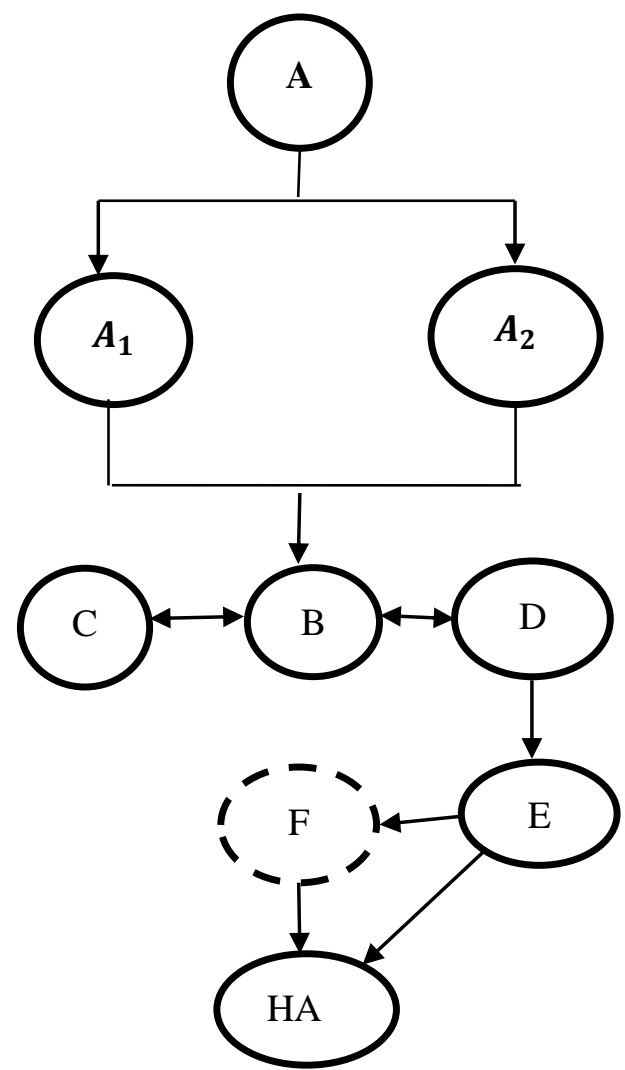

Figure 1: Thinking Structure of Students in Solving Problems

Table 2. Code description of the figure

\begin{tabular}{|c|c|}
\hline Code & Explanation \\
\hline A & $\begin{array}{l}\text { Understanding the meaning of functions in the problem of derivative } \\
\text { algebraic functions that have been given }\end{array}$ \\
\hline$A_{1}$ & $\begin{array}{l}\text { Understanding the known infromation of problems related to } \\
\text { functions }\end{array}$ \\
\hline$A_{2}$ & Understanding the asked in questions related to functions \\
\hline $\mathrm{B}$ & Understanding the definition of a derivative of an algebraic function \\
\hline $\mathrm{C}$ & Understanding the rules of derivative functions in algebra \\
\hline $\mathrm{D}$ & Rationalizing the root form \\
\hline $\mathrm{E}$ & Operating integer operations in algebra \\
\hline $\mathrm{F}$ & Simplifying the root form \\
\hline HA & $\begin{array}{l}\text { Determining the first derivative of the given problem derivative } \\
\text { algebra function }\end{array}$ \\
\hline
\end{tabular}

Information : ‘) It means that it is conditional (can be done or not) 


\section{RESULTS AND DISCUSSION}

The data analysis is data from students who have procedural errors in the Derivative of Algebraic Functions. Before data collection is carried out, first make preparations by making questions that will be used to see students' procedural errors. The obtained data are then sorted based on the level of procedural errors. Regarding these results, it is continued by conducting interviews with students to find out the complete flow of students' thinking in solving the problems.

Based on the results of the essay test instrument from 25 students, some students indicate that there is a procedural error in the first question. Of the several mistakes made by students, there are 6 children who experience procedural errors but they are still in a reasonable stage, and the answers are more or less the same so they needed to be deduced. Based on the results of the reduction, it is found that one of the students experience procedural errors and had a unique flow of thought and can apply basic concepts in solving the problems. The students experience procedural errors at the stage of implementing the problem-solving plan and at the stage of checking again. The types of procedural errors made by students are the types of error repair theory and overspecialization.

The error analysis refers to the procedural error theory according to Elbrink which is adjusted to the problem-solving stages of Polya. The results of the analysis are described as follows.

\section{Students' Procedural Errors in Solving Derivative Problems of Algebraic Functions}

Based on the results of written test data and interviews of research subjects, firstly, the process of analyzing procedural errors carried out by students in solving the given mathematical problems by referring to the problemsolving stages according to Polya. The results of the analysis are as follows.

\section{Understanding the Problem}

The research subjects can sort and collect important information in the questions. Furthermore, students already understand what is known and what is being asked informatikon. Regarding the results of the interview, it is shown that the students took the first problem-solving stage, namely understanding the problem.

2. Creating a Problem-Solving Plan

The results of students work can be seen in Figure 2.

$$
\text { (1.) } \begin{aligned}
f(x) & =\sqrt{x+2} \rightarrow f(x)=(x+2)^{\frac{1}{2}} \\
f^{\prime}(x) & =\frac{1}{2}(x+2)^{-\frac{1}{2}} \\
& =\frac{1}{2(x+2)^{\frac{1}{2}}}
\end{aligned}
$$

Figure 2. Students' worksheet

The stage of making a problemsolving plan is the stage where the research subject makes generalizations about a concept and determines a strategy in solving the given problem. Based on the results of students' work, students carry out the second problemsolving stage, namely the stage of making a problem-solving plan well. This is reinforced by the results of interviews with research subjects which show that students can study alternative problem solutions that are used by changing the root form using the properties of the root and then using the usual formula of the derivative, namely 
if there is $a^{n}$ then the derivative becomes $n \times a^{n-1}$.

Based on the results of interviews and student work sheet, it is found that the research subject can assimilate the information contained in the questions into a mathematical form by using the concept of the derivative of algebraic functions.

3. Carrying out a Problem-Solving Plan

The stage of implementing the problem-solving plan is where the research subject performs the calculation process of the strategy to solve the given problem, applies an algorithm to a given problem, and has a clear direction of work in solving the problem. The following are the results of students' work in solving the questions given in Figure 3 .

$$
\begin{aligned}
& =\frac{1}{2 \sqrt{x+2}} \times \frac{2 \sqrt{x+2}}{2 \sqrt{x+2}} \\
& =\frac{12 \sqrt{x+2}}{21(x+2)} \\
& =\frac{2 \sqrt{x+2}}{4 x+8} \text { Repair Theory } \\
& =\frac{1 \sqrt{x+2}}{2(x+2)} \\
& =\frac{\sqrt{x+2}}{2 x+2}
\end{aligned}
$$

Figure 3. Final Results of Students'

\section{Worksheet}

Based on the results of students' work, students carry out the stages of implementing the problem-solving plan. This is reinforced by the results of interviews with research subjects which show that the research subject understands the concept of derivatives well, can explain in detail what is meant by derivatives in the questions. Furthermore, the research subject also said that the final result of the answer is obtained by rationalizing the root form in the problem. The purpose of rationalizing the root is to remove the root form in the denominator. This shows that the research subject committs overspecialization procedural errors.

Thus, based on the results of the interviews and the final results of the work from the students, it is found that the students had already carried out the stages of implementing the problemsolving plan. Students can assimilate the information contained in the questions (problems), that is, they can explain the meaning derivatives, explain the next step after obtaining the derivative results. Even so, students make mistakes in determining the final result where they have not been able to apply the algorithm to rationalize the root form of the problems that have been given. Where the concept of rationalizing is still wrong, students assume that rationalizing the root is to eliminate the root form in the denominator by multiplying the friend form. However, it is not the mutual form that is multiplied, but the original root form which is multiplied because of removing the denominator's root form into a permanent root form.

\section{Rechecking}

At this stage, students can provide procedural limitations in solving problems with the final results of the problems. At this stage, the students do not double-check the results of their answers due to the limited time in the process. At this stage, the students are required to double-check whether the answer is correct or not. Based on the results of the interviews, it shows that students hesitate when asked about the final results of their answers, which can be seen from the expressions on students' faces when being interviewed. 
Based on the results of the interview, it is found that students make mistakes in solving the problem by not checking the final result again so that the answer should be correct but it becomes wrong because they are not thorough and do not understand the concept of rationalizing the roots properly and correctly.

Based on the results of the error analysis, (Elbrink, 2011) states that the errors that may arise in solving math problems are calculating errors and procedural errors. Calculation errors arise when students are careless in doing calculations when solving math problems, while procedural errors occur not only because of carelessness, but also because they do not have a good conceptual understanding in mathematics. Furthermore, (Elbrink, 2011) argues that procedural errors arise when students do not understand the steps taken, as well as why and how the problem-solving process can be applied in problem-solving.

Based on the results of the answers and the interviews, it is found that the research subjects experience an error in repair theory and overspecialization. Error repair theory is carried out by research subjects when the students are wrong in rationalizing the root form and determining the result which should not necessarily rationalize the results but the results of the rational are wrong. This shows that students do not understand the concept of rationalizing and simplifying the root form. Then, the overspecialization error occurs because students assume that rationalizing the root form is by multiplying the mutual form by removing the root form from the denominator, but students do not understand the concept of the mutual in integer operations. The existence of procedural errors experienced by students does not mean that they are unable to solve the given problems, it's merely the plan used by the research subject to solve the question. To explain further, the following Figure 4 is presented. The explanation of Figure 4 can be seen in Table 3 .

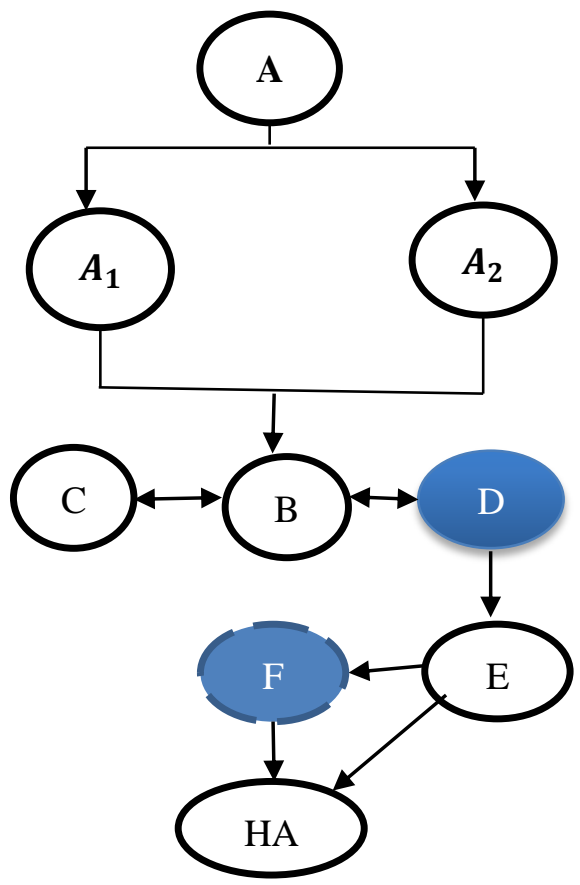

Figure 4. Thinking Structur of Research Subjects Before Defragmentation

Table 3. Code Description in the image

\begin{tabular}{cl}
\hline Code & \multicolumn{1}{c}{ Explanation } \\
\hline $\mathrm{A}$ & $\begin{array}{l}\text { Understanding the meaning of functions in the question of derived } \\
\text { algebraic functions that have been given }\end{array}$ \\
$A_{1}$ & Understanding the known information related to functions \\
$A_{2}$ & Understanding the asked information related to functions \\
$\mathrm{B}$ & Understanding the definition of a derivative of an algebraic function \\
\hline
\end{tabular}


DOI: https://doi.org/10.24127/ajpm.v10i1.3441

\begin{tabular}{cl}
\hline Code & \multicolumn{1}{c}{ Explanation } \\
\hline C & Understanding the rules of derivative functions in algebra \\
D & Rationalizing the root form \\
E & Operating integer operations in algebra \\
F & $\begin{array}{l}\text { Simplify the root form } \\
\text { HA }\end{array}$ \\
& $\begin{array}{l}\text { Determining the first derivative of the given problem derivative } \\
\text { algebra function }\end{array}$ \\
nformation : & It means that it is conditional (can be done or not) \\
& It means that students experience errors
\end{tabular}

After knowing the types of mistakes made by the research subject and their thinking structure, it can be done through the defragmenting process as an effort to overcome the mistakes made by the research subject.

\section{The Process of Defragmentation Structural Thinking in Solving Derivative Problems of Algebraic Functions}

After knowing the location of the thinking structure that is not knitted well, the researchers then carries out a defragmentation process to rearrange the thinking structure of the research subject so that it becomes a more complete thinking structure. Based on the thinking structure of research subjects, the researchers need to correct procedural errors made by the subject. Where the subject makes a repair theory error and overspecialization when solving a given problem so that the subject still experiences defragmentation, namely mathematical concepts that have not been stored properly in the students' memory.

The initial defragmentation carried out by the researcher is disequilibration, namely by creating a condition of gaps in the mind of the research subject, or it can be said to raise suspicion so that the research subject can reflect on his answer.

This is indicated by the results of the interviews where students seem doubtful when asked whether the results of the answers are correct or not. Furthermore, students are given time to think and reflect by re-reading the problems. After that, they are given a question about the form of the root obtained, namely $\frac{1}{2 \sqrt{x+2}}$ if how many friends are being held together. Then from the results of the interviews, the research subjects said that the peer form of these roots has a fixed value. This is because the research subject aims to eliminate the root form of the denominator and when asked once again whether the rational form of the root is like the result of the answer, the research subject is silent seems to think again about the question.

Based on the results of the interview, the students seem to realize that the final result is wrong, but they can't provide the right solution to the problem. Furthermore, the defragmenting process is carried out again with the aim of rearranging the students' thinking structure by providing scaffolding, namely by providing an example of rationalizing the root form of $\frac{1}{\sqrt{x+2}-\sqrt{x-3}}$ and students are asked to explain how to rationalize these roots. In addition, also by inviting students to re-correct the completion process that has been written along with the students' final results and conclusions.

Based on the results of the interview, it is found that the students realize where the mistakes are. That is, 
the process carried out is a process of simplifying the root form instead of rationalizing the root form. Furthermore, the students are asked to check the results of their work again and it is found that the results are wrong results, then the correct answer is shown in Figure 5.

Based on the results of the interview, it is found that the research subjects can determine the possible solutions of the derived algebraic functions. Then the researchers ask the research subject to determine the true final result. In this case, the research subjects have no difficulty at all because they realize that the result of the answer is wrong. The Figure 5 is the results of the research subjects' in determining the actual final result.

$$
\text { (1) } \begin{aligned}
f(x) & =\sqrt{x+2}-\frac{1}{2}\left(x(x)=(x+2)^{\frac{1}{2}}\right. \\
f^{\prime}(x) & =\frac{1}{2}(x+2)^{\frac{1}{2}-1} \\
& =\frac{1}{2}(x+2)^{-\frac{1}{2}} \\
& =\frac{1}{2(x+2)^{\frac{1}{2}}} \\
& =\frac{\left.\frac{1}{2 \sqrt{x+2}}\right)^{\frac{2 \sqrt{x+2}}{2 \sqrt{x+2}}}}{\frac{3 \sqrt{x+2}}{4(x+2)}} \\
\text { samigan } \Rightarrow & =\frac{2 \sqrt{x+2}}{4 x+8} \\
\text { sini saja } \Rightarrow & \frac{\frac{1}{2}(x+2}{2(x+2)} \\
& =\frac{\sqrt{x+2}}{2 x+4} \text { bouns }
\end{aligned}
$$

Figure 5. Students' work in determining the set of solutions by defragmentation
The defragmenting process is carried out as described, it can be concluded that the students manage to find a solution to the problem, namely $\frac{1}{2 \sqrt{x+2}}$. After the defragmenting process, the student's thinking structure is finally correct and students can correct their mistakes and the structure of their thinking. This thinking structure can be described in Figure 6. For the explanation of Figure 6 can be seen in Table 4.

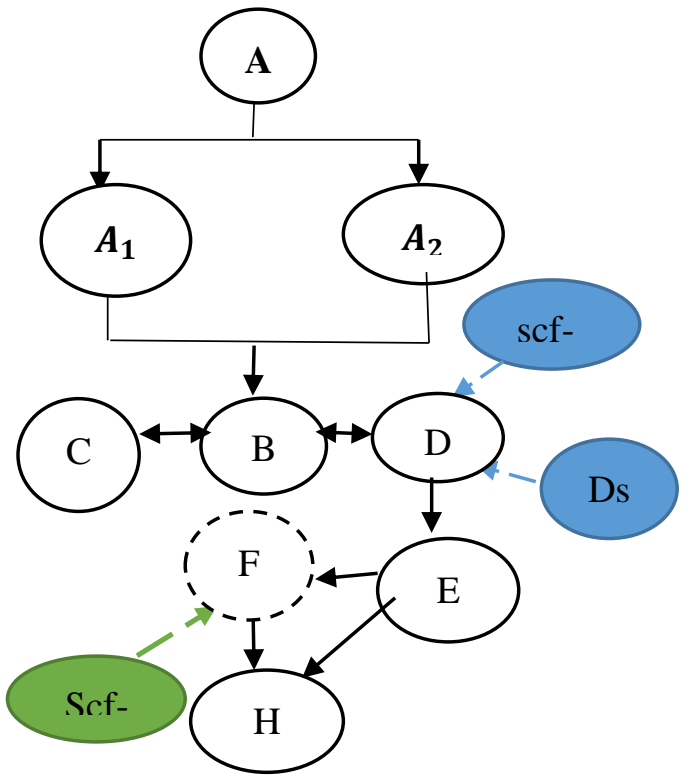

Figure 6. Thinking structure of research subjects by defragmentation

Table 4. Description of the defragmenting process code

\begin{tabular}{ll}
\hline Defragmenting code & \multicolumn{1}{c}{ Explanation } \\
\hline Ds (Disequalibrasi) & $\begin{array}{l}\text { Giving questions to the research subjects mutual form of } \\
\text { Scf-1 (Scaffolding-1) }\end{array}$ \\
$\begin{array}{l}\frac{1}{2 \sqrt{x+2}} \\
\text { Giving questions to the research subjects } \frac{1}{\sqrt{x+2}-\sqrt{x-3}} \text { try to } \\
\text { explain the rationalized form }\end{array}$ \\
$\begin{array}{l}\text { Giving questions to the research subjects to see the work } \\
\text { process. the way to be done is a way of rationalizing the root } \\
\text { form or simplifying it and re-checking the final results } \\
\text { obtained by the students are the final results or not. }\end{array}$ \\
\hline
\end{tabular}


Based on the results, it is shown that at the stage of implementing the problem-s olving plan and checking again students experience procedural errors. These errors can be corrected through the defragmenting process by performing a disequalibration and scaffolding process. This is in line with the research conducted by (Septian \& Chandra, 2018) which reveals that students' mistakes in understanding story problems and implementing problem-solving plans can be corrected through the defragmenting process after calibration. Whereas students' errors at the stage of re-checking procedures and the results of completion can be corrected through the defragmenting process disequalibration and scaffolding.

The implication of this research is to help teachers develop the mathematics learning process as a whole with the correct concept, students are more confident in delivering the answers they get, students will not make the same mistakes continuously, students are more careful in doing everything they can conduct activities to re-examine the answers in a conceptual and structured manner so that it has an impact on their learning achievement and students can develop their potential without having to worry about the results obtained.

\section{CONCLUSION AND SUGGESTION}

Based on the results of research and discussion, it was found that students experienced procedural errors. Based on Elbrink's theory, students do the types of error repair theory and overspecialization. This type of error occurs at the stage of executing the problem-solving plan and rechecking. This stage is a problem stage according to Polya. To overcome this error, this research carried out the defragmenting process by providing assistance in the form of disequilibration and scaffolding. Both treatments make the students' thinking structure into a complete thinking structure, so that they can solve problems appropriately and avoid mistakes.

As for suggestions for further research on defragmentation the structure of students' thinking should be more detailed and broad. The research should be carried out at a higher level, for example in universities. The research subjects are not only one, but more than it. Besides, using different stages as well as different types of errors to enrich the results.

\section{REFERENCES}

Agustina, R. (2014). Proses Berpikir Siswa SMA dalam Penyelesaian Masalah Aplikasi Turunan Fungsi Ditinjau Dari Tipe Kepribadian Tipologi Hippocrates-Galenus. Tesis tidak diterbitkan. Surakarta: Universitas Sebelas Maret.

Amir, M.F. (2015). Analisis Kesalahan Mahasiswa PGSD Universitas Muhammadiyah Sidoarjo dalam Menyelesaikan Soal Pertidaksamaan Linear. Jurnal Edukasi, 2(1), 131-145.

Apriliyanto, B. (2019). Analisis Kesalahan Siswa dalam Pemecahan Masalah Turunan Fungsi Aljabar. Jurnal Komunikasi Pendidikan, 3(2), 117-125. https://doi.org/10.32585/jkp.v3i2.3 $\underline{00}$

Bahrudin, M. A., Indrawatiningsih, N., \& Nazihah, Z. (2019). Defragmenting Struktur Berpikir Siswa SMP Dalam Menyelesaikan Masalah Bangun Datar. IndoMath: Indonesia Mathematics Education, 2(2), 127-140. 
DOI: https://doi.org/10.24127/ajpm.v10i1.3441

https://doi.org/10.30738/indomath. $\mathrm{v} 2 \mathrm{i} 2.4701$

Efendi, J. F., \& Pratama, R. A. (2020). Defragmenting Proses Berpikir Pseudo Siswa Dalam Menyelesaikan Masalah Matematika. AKSIOMA: Jurnal Program Studi Pendidikan Matematika, 9(3), 651-661. https://doi.org/10.24127/ajpm.v9i3. 2956

Elbrink, M. (2011). Analyzing and Addressing Common Mathematical Errors in Secondary Education. Undergraduate Mathematics Exchange, 05(1), 1-61.

Kumalasari, F. (2016). Defragmenting Struktur Berpikir Siswa dalam Menyelesaikan Masalah Pertidaksamaan Eksponen. Tesis Tidak Terbitkan. Malang: Universitas Negeri Malang.

Kumalasari, F., Nusantara, T., \& Sa'dijah, C. (2016). Defragmenting Struktur Berpikir Siswa Dalam Menyelesaikan Masalah Pertidaksamaan Eksponen. Jurnal Pendidikan: Teori, Penelitian dan Pengembangan, 1(2), 246-255. https://doi.org/10.17977/jp.v1i2.61 29

Naisunis, Y. P., Taneo, P. N. L., \& Daniel, F. (2018). Analisis Kesalahan Mahasiswa dalam Pemecahan Masalah pada Mata Kuliah Persamaaan Diferensial. Edumatica, 08(2), 107-119.

National Council of Teachers of Mathematics (Ed.). (2000). Principles and standards for school mathematics. National Council of Teachers of Mathematics.

Septian, A. D., \& Chandra, T. D. (2018). Defragmentasi Struktur Berpikir Siswa Impulsif dalam Menyelesaikan Soal Cerita. Jurnal
Pendidikan: Teori, Penelitian dan Pengembangan, 3(8), 994-1011.

Subanji. (2015). Teori Kesalahan Konstruksi Konsep dan Pemecahan Masalah. Malang: UM Press

Subanji. (2016). Teori Defragmentasi Struktur Berpikir dalam Mengonstruksi Konsep dan Pemecahan Masalah Matematika. Malang: UM Press

Wibawa, K. A., \& Chandra, T. D. (2013). Defragmenting Berpikir Pseudo Siswa Dalam Memecahkan Masalah Limit Fungsi. Prosiding 2 Seminar Nasional Exchange of Experiences Teacher Quality Improvement Program (TEQIP), 721-740.

https://www.researchgate.net/public ation/28558120621.

Wibawa, K. A. (2016). Defragmenting Struktur Berpikir Pseudo dalam Memecahkan Masalah Matematika. Yogyakarta: Deepublish.

Wibawa, K. A., Nusantara, T., Subanji, S., \& Parta, I. N. (2017). Fragmentation of Thinking Structure's Students to Solving the Problem of Application Definite Integral in Area. International Education Studies, 10(5), 48-60. https://doi.org/10.5539/ies.v10n5p4 8

Wibawa, K. A., Nusantara, T., Subanji, S., \& Parta, I. N. (2018). Defragmentasi Pengaktifan Skema Mahasiswa Untuk Memperbaiki Terjadinya Berpikir Pseudo Dalam Memecahkan Masalah Matematis. Prima: Jurnal Pendidikan Matematika, 2(2), 93-106. https://doi.org/10.31000/prima.v2i2 .755 